\title{
Microbiological Characteristics of Biohumus and Humin Extract
}

\author{
Anna Gneush ${ }^{1}$, Inna Zholobova ${ }^{1}$, Alexander Petenko ${ }^{1}$, Darya Antipova ${ }^{2}$, and \\ Denis Yurin² \\ ${ }^{1}$ Federal State Budgetary Educational Institution of Higher Education "Kuban State Agrarian \\ University named after I.T. Trubilin", Krasnodar, Russian Federation \\ ${ }^{2}$ Krasnodar Research Centre for Animal Husbandry and Veterinary Medicine, Krasnodar, Russian \\ Federation
}

\section{ORCID:}

Anna Gneush: http://orcid.org/0000-0003-4931-795X

Denis Yurin: $h$ ttp://orcid.org/0000-0003-1517-4858

\section{Abstract}

This article describes the technology of biohumus and humic extract production and their microbiological characteristics. We developed technology from cattle manure and winter wheat straw in a biodynamic fermenter to obtain biohumus. The

Corresponding Author:

Denis Yurin

4806144@mail.ru

Published: 5 April 2021

Publishing services provided by

Knowledge E

(c) Anna Gneush et al. This article is distributed under the terms of the Creative Commons Attribution License, which permits unrestricted use and redistribution provided that the original author and source are credited.

Selection and Peer-review under the responsibility of the DonAgro Conference Committee. received biohumus and the humic extract recovered therefrom were subjected to microbiological analysis. The largest physiological groups of microorganisms in the biohumus were aminoautotrophic microorganisms and ammonifiers. The influence of humic extraction on soil mycobiota was estimated which showed that 30 days after the processing of soil by humic extraction, the quantity of phytopathogenic micromycetes of genus Fusarium decreased by 3.9 times and of genus Penicillium by 1.2 times. The quantity of micromycetes of genus Aspergillus largely did not change, and the quantity of micromycetes saprophytes of genus Trichoderma increased by 2.0 times. After the humic extract treatment, the ratio of saprophytic and pathogenic groups of microscopic fungus in the soil was more than 10 , which ensured their sufficient suppression. Thus, the phytosanitary state of the tested soil sample after treatment with humic extract significantly improved, which made it possible to recommend the use of humic extract for soil treatment not only as an organic fertilizer, but also for the purpose of reducing the content of phytopathogenic microscopic fungus therein.

Keywords: biohumus, humic extract, soil, microorganisms, microscopic fungus, phytosanitary state

\section{Introduction}

In wildlife, there is a large number of microorganisms actively decomposing cellulose to monostructures. Cellulolytics are found among bacteria, actinomycetes and micromycetes. The most studied ones are representatives of the fungus Aspergillus and Trichoderma, widely used in industrial production of enzyme preparations. 
Bacteria of the genus Clostridium are thermophilic ethanologous anaerobic bacteria represented by $\mathrm{C}$. thermocellus, $\mathrm{C}$. thermohidrosulfuricum. The latter representative is thermophilic; C. thermocellum shows high catalytic activity as cellulolytic. In nature they are widespread, can be isolated from soil, thermal sources, silt, manure and rotting organic substrate [1-3].

C. thermocellum is a bond anaerob, spawning at high temperatures up to $60^{\circ} \mathrm{C}$. It hydrolyses cellulose, hemicellulose and cellobiose with release of ethyl alcohol, acetic and lactic acids, hydrogen and carbon dioxide during metabolism. C. thermocellum forms stable synthrophic associations with other species of bacteria. In association, they actively cleave cellulose, delignified cellulose pulp, steamed wood.

When $\mathrm{C}$. thermocellum strains are cultured on cellulose, they form a cellulase complex. In general, C. thermocellum cellulase system differs from fungal (Trichoderma viride or T. reesei). Clostridium cellulase breaks down microcrystalline cellulose twice as slowly as the enzyme produced by the Seesei fungus.

Cellulolytic bacteria with delignifying ability are introduced into the composition to improve productivity of direct bioconversion of lignocellulose substrates. Basidial fungus are brown and soft rot, white rot fungus causing wood to rot capable of destroying lignin, using it as the only carbon source. Among bacteria, the genera Corynebacterium, Pseudomonas, Klebsiella, which can decompose up to $98 \%$ of industrial lignin in a few days, attract special attention [4-7].

The raw material base for the process of bioconversion of industrial cellulosecontaining wastes is extensive. Industrial wastes containing cellulose are complex compounds which, in addition to cellulose, contain substances of aromatic series, toxic components. The process of recycling these wastes cannot but affect the growth and development of microorganisms, it is possible to inhibit the growth of bacteria by some raw material compounds. The degree of conversion of the feedstock will be different using different cellulose-containing substrates.

Fermentation products used as fertilizers should have high biological activity and nutritional value. Such properties of final products are formed as a result of the development of microorganisms under the influence of changing physical and chemical parameters of the environment. Knowledge of fermentation processes makes it possible to carry out a directed process of fermentation of organic mass with subsequent production of biohumus and extraction of humic compounds from it [8-10].

The problem of biotechnology of humic compounds from affordable and inexpensive raw materials is now quite acute for manufacturers. To date, technologies for the production of organic fertilizers with high content of humic compounds have already 
been developed and introduced into practice, namely technological schemes providing thermochemical treatment of raw materials, methods for the production of humic preparations without preheating using strong oxidants, chlorine, ozonized air, ozone, concentrated inorganic acids, nitrogen oxide, etc. All the proposed methods allow one to obtain organic fertilizers with high yield of humic substances [11-13].

Humic compounds are organic molecules having high molecular weight. The main task facing organic fertilizer manufacturers is to obtain the form of humic compounds available to plants.

In addition to humic and fulvic acids, humic compounds contain amino acids, carbohydrates, vitamins, macro- and microelements, hormone-like compounds. All the main components of humic compounds are characterized by stability, polydispersity, polyfunctivity and have sorption, ion exchange properties and a wide range of biological action [14-16].

All humic compounds have similar composition and structure, but depending on the raw material, the method of extraction their chemical structure can change, and with it their physiological activity changes.

The aim of the work was to develop technology for obtaining humic compounds from biohumus and to study its microbiological parameters.

The following tasks were set:

1. to describe the technology of producing biohumus;

2. to determine the numerical composition of the main physiological groups of microorganisms involved in the process of formation of biohumus;

3. to analyze the numerical composition of the main physiological groups of microorganisms in humic extraction;

4. to analyze the number of main physiological groups of microorganisms and microscopic fungus before and after soil treatment in humic exhaust.

\section{Methods and Equipment}

Biohumus was obtained according to our developed technology from cattle manure and winter wheat straw in a biodynamic fermenter measuring of $12 \times 4 \times 2.5$ meters, equipped with a system of gutters in the bottom, providing liquid outflow. A mixture of 72 tonnes of cattle manure and 9 tonnes of straw cutting ground to the fraction of 1-20 centimeters moistened to a relative humidity of $65 \%$ ( 81 tonnes total) was prepared and placed in the fermenter. The mixture was stirred periodically and its temperature was 
monitored under the influence of aboriginal microorganisms. After 125 hours, the mixture was warmed to $75^{\circ} \mathrm{C}$ and the collection of humic extract was started, which was put into the collection vessel through the trough system. The moisture content of the mass in the biodynamic fermenter was maintained at $65 \%$. The process of extraction of humic extract lasted 72-90 hours and ended with reduction of biohumus mass temperature to $50^{\circ} \mathrm{C}$. As a result of one cycle of biodegradation of 81 tons of organic matter in the bio-fermenter, 4,000 litres of humic extract were obtained.

The biohumus obtained and the humic extract recovered therefrom were subjected to microbiological analysis. For this purpose samples of biohumate were taken from the biofermenter 5 days after the beginning of fermentation of the mixture of manure and straw cutting, and samples of humic extract - after its concentration. Microbiological analysis was performed on the 2 of a biohumus sample and humic extract in triplicate. In the biohumus and humin extract samples tested, the total number of aerobes was determined using the Petrifilm AC system, as well as the main groups of microorganisms of autochthonous microflora microbiocenosis of biogumus: ammonifiers (on the environment of meat peptonic agar), aminoautotrophies (on the environment of starch ammonium agar), actinomycetes (on the environment of starch ammonium agar), oligonitrophils and nitrogen fixators (on Ashby environment), microscopic fungus (on Chapek environment).

The number of microscopic fungus in soil was determined in accordance with methodological instructions "Methods of microbiological control of soil" (approved on 24.12.2004). The bacteria of E. coli group, helminth larvae in biohumus were determined in accordance with state standard 17.4.4.02-2017, sanitary rules and regulations 2.1.7.1287-03, methodological instructions 2.1.7.730-99.

At the initial stage of composting the manure had bright brown colour, a sharp smell of ammonia, humidity up to $75 \%$. To prepare the compost mixture, the straw slitting was mixed with the manure on the concrete platform. At the bottom of the biodynamic fermenter straw cutting in the form of a $0.2 \mathrm{~m}$ high pad was laid and then the fermenter was loaded with this product completely. The volume of the fermenter is $80 \mathrm{~m}^{3}$. After loading the fermenter, the compost mixture was spilled with $2-3 \mathrm{~m}^{3}$ of water depending on the initial humidity. Throughout the whole cycle we recorded the following technologically important indicators: temperature, humidity, density, acidity. On the second day of fermentation we carried out aeration in automatic mode for 1 hour under pressure of 10 atmospheres. As a result of increasing the number of thermophilic microorganisms, on the sixth day of the experiment the temperature in the organic mass rose to $70^{\circ} \mathrm{C}$. In 10 days the fermenter was reloaded. 
The compost of the fermenter was laid on a concrete pad, mixed and put back into the fermenter, previously prepared according to the same scheme as at the beginning of fermentation. At this stage, the biohumus becomes dark and is deprived of ammonia smell. The fermentable mass was discharged from the fermenter as a ready biohumus after 12 days. During this time, biohumus acquired an even more saturated black color and a tangible smell of soil. The finished product was unloaded to the concrete site where it was dried to $55 \%$ humidity.

\section{Results and Discussion}

Microbiological analysis in biohumus revealed a high number of microorganisms involved in organic decomposition (Table 1).

TABLE 1: Number of main physiological groups of microorganisms, participating in the process of biohumus formation.

Physiological and taxonomic groups of microorganisms
Total number of aerobs, $10^{6} \mathrm{CFU} / \mathrm{g}$
Ammonifiers, $10^{6} \mathrm{CFU} / \mathrm{g}$
Aminoautotrophs, $10^{6} \mathrm{CFU} / \mathrm{g}$
Oligonitrophils and nitrogen fixators, $10^{6} \mathrm{CFU} / \mathrm{g}$
Actinomycetes, $10^{3} \mathrm{CFU} / \mathrm{g}$
Micromycetes, $10^{3} \mathrm{CFU} / \mathrm{g}$

Number of microorganisms
$\begin{gathered}48.32 \pm 4.85 \\ 130.33 \pm 18.67 \\ 231.60 \pm 23.68 \\ 71.20 \pm 21.51 \\ 0.93 \pm 0.58 \\ 8.67 \pm 1.15\end{gathered}$

The largest physiological group of microorganisms in the biohumus under study is represented by aminoautotrophic microorganisms, the number of which was $231.6 \times$ $10^{6} \mathrm{CFU} / \mathrm{g}$. This appears to be due to the preponderance of plant-derived organics in the processed mass. The number of ammonifiers was 1.8 times lower than that of aminoautotrophies and was $130.33 \times 10^{6} \mathrm{CFU} / \mathrm{g}$. The prevalence of the aminoautotrophic group over ammonifiers indicates a sufficiently high degree of mineralization of the compost.

The number of cellulose-destroying actinomycetes in the biohumus under study was $0.93 \times 10^{3} \mathrm{CFU} / \mathrm{g}$, which is quite a large microbial community for this class of microorganisms, which is essential for humification and for self-purification of compost from opportunistic microorganisms.

At the same time, the humic extract was characterized by the presence of all microbial groups characteristic of biohumus (Table 2). The humic extract also noted a rather high number of microorganisms involved in organic decomposition. 
TABLE 2: Number of main physiological groups of microorganisms in a humic extract.

Physiological and taxonomic groups microorganisms
Total aerobes, $10^{6} \mathrm{CFU} / \mathrm{g}$
Ammonifiers, $10^{6} \mathrm{CFU} / \mathrm{g}$
Aminoautotrophs, $10^{6} \mathrm{CFU} / \mathrm{g}$
Oligonitrophils and nitrogen fixators, $10^{6} \mathrm{CFU} / \mathrm{g}$
Actinomycetes, $10^{3} \mathrm{CFU} / \mathrm{g}$
Microscopic fungus, $10^{3} \mathrm{CFU} / \mathrm{g}$

\begin{tabular}{|c|}
\hline Number of microorganisms \\
\hline $3.31 \pm 0.25$ \\
\hline $11.23 \pm 1.05$ \\
\hline $6.13 \pm 1.50$ \\
\hline $1.05 \pm 0.84$ \\
\hline $0.05 \pm 0.03$ \\
\hline $0.27 \pm 0.12$ \\
\hline
\end{tabular}

At the same time, the number of aminoatrophs was 1.8 times lower than the number of ammonifier groups $-6.13 \times 10^{6}$ vs. $11.23 \times 10^{6} \mathrm{CFU} / \mathrm{g}$ (Figure 1). This may be due to the fact that ammonifiers were more resistant to changes in $\mathrm{pH}$ of the environment in the alkaline direction.

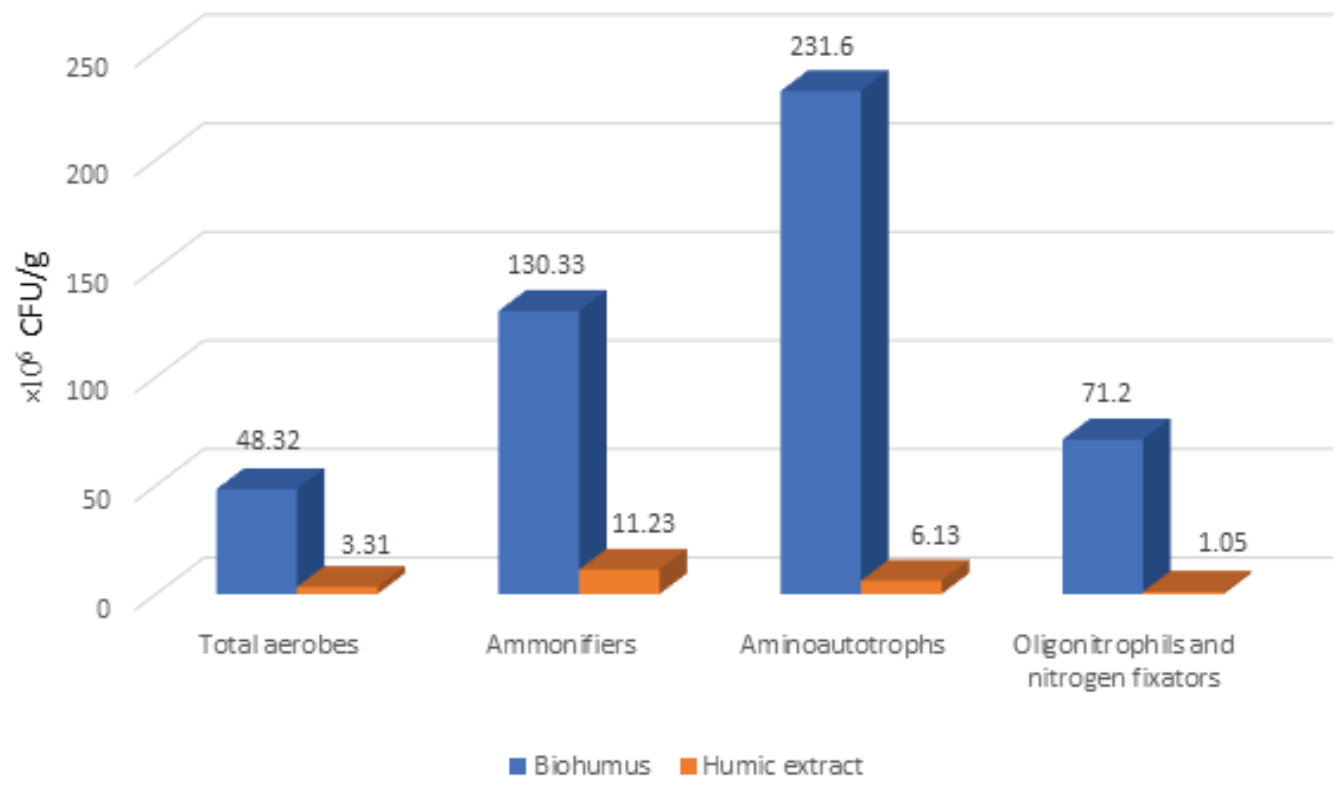

Figure 1: The ratio of main physiological groups of microorganisms in biohumus and humic extract.

The presence of actinomycetes and micromycetes in the humic extract was noted, but the number of mycelial microorganisms was quite low. This is because these microorganisms are more strongly bound to the substrate and not so actively transferred to the humic extract (biohumate).

In the next step, the experiment was conducted to assess the effect of humic extract on soil mycobiota, as the level of organic substances, including humic compounds, affects the number and composition of soil microbiocenosis. 
For this purpose, mycological analysis of soil sample intended for humic extract application was performed beforehand. The results of the mycological study are shown in Table 3.

TABLE 3: Number of microscopic fungus in soil prior to humic treatment extract.

Microscopic fungus
Aspergillius $s p$.
Fusarium $s p$.
Penicillium $s p$.
Trichoderma $s p$.
Ecological and trophic groups of microscopic fungus
saprophytes
pathogens
saprophytes: pathogens

Soil content in native sample,
$\times 10^{3} \mathrm{CFU} / \mathrm{g}$
28.6
5.4
8.2
1.4

38.2
5.4
7.1

Analysis of the results showed that in the test sample the proportion of micromycetes capable of causing phytotoxicosis of soil is more than $50 \%$ of mycobiota, which negatively affects the growth, development and immunity of plants cultivated on these soils.

The ratio of ecological-trophic groups of microscopic fungus in the sample (saprophytes: pathogens) was less than 10 , which does not provide sufficient soil suppressivity (ability to reduce the number of phytopathogenic microscopic fungus).

The absence of fungus of the Zygomycetes class in the samples indicates the low ability of the soil to decompose the burning residues. Thus, the soil sample studied is not favourable in phytosanitary terms.

The soil sample was then treated with a humic extract of $0.1 \mathrm{~L}$ per $1 \mathrm{~kg}$ of soil at a concentration of $5 \mathrm{~g} / \mathrm{L}$. The soil maintained a constant level of humidity and temperature. After 30 days, a repeated mycological analysis of the soil was performed, the results of which are shown in Table 4.

The results of the mycological study of soil after treatment with humic extract showed that the amount of phytopathogenic micromycetes of Fusarium genus in it decreased 3.9 times (Figure 2).

There was also a slight decrease in the number of micromycetes of the genus Penicillium - 1.2 times. At the same time, the number of micromycets of the genus Aspergillus has hardly changed. Treatment of soil with humic extraction has promoted increase in population of saprophyte group of micromycetes of genus Trichoderma 2.0 times. 
TABLE 4: Number of microscopic fungus in soil (number of propane per $1 \mathrm{~g}$ of dry soil, thousands) after treatment of humic hoods.

\begin{tabular}{l|c} 
Microscopic fungus & $\begin{array}{c}\text { Soil content in native sample, } \\
\times 10^{3} \text { CFU/g }\end{array}$ \\
\hline Aspergillius sp. & 27.8 \\
Fusarium $s p$. & 1.4 \\
Penicillium $s p$. & 6.9 \\
Trichoderma sp. & 2.8 \\
Ecological and trophic groups of microscopic fungus: & \\
saprophytes & 37.5 \\
pathogens & 1.4 \\
saprophytes: pathogens & 26.8
\end{tabular}

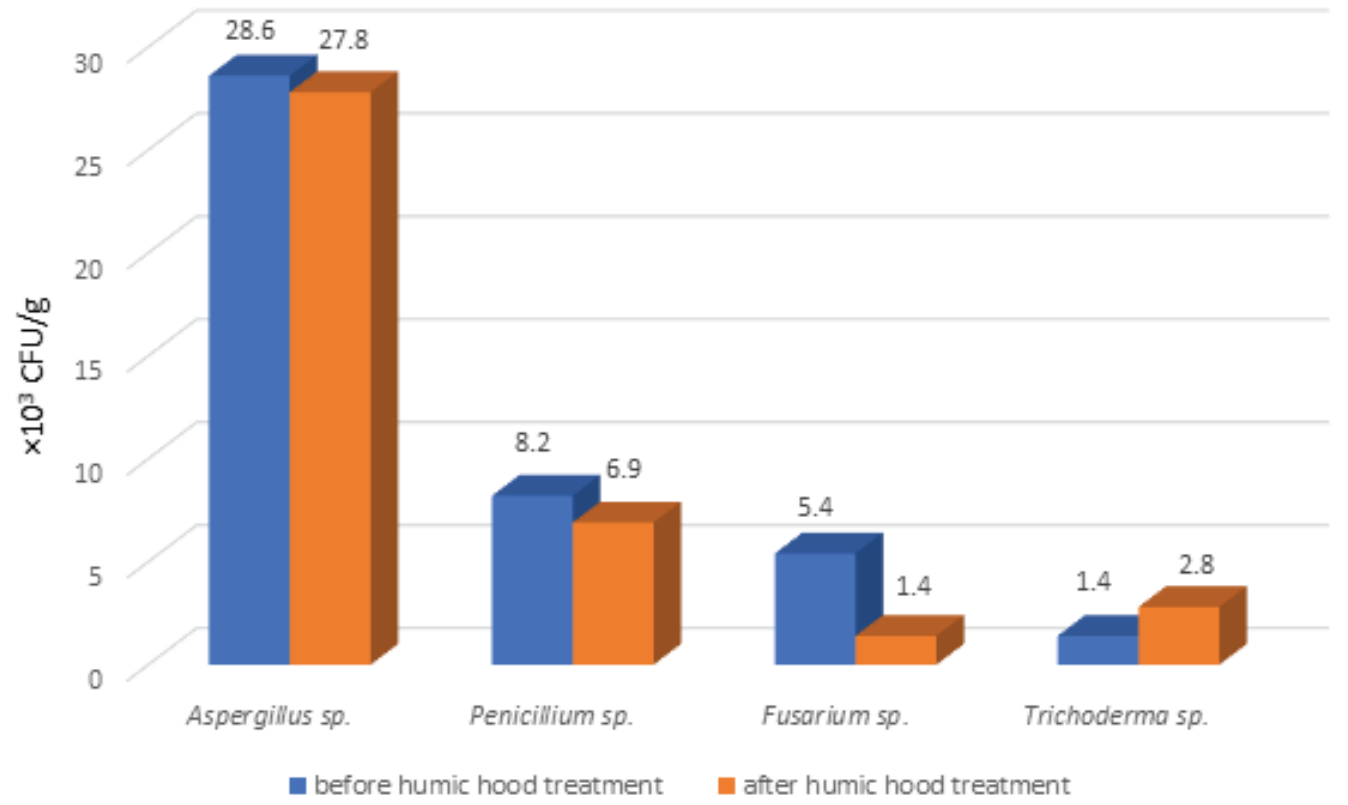

Figure 2: Dynamics of micromycete numbers in soil before and after humic hood treatment.

After treatment with humic extract, ratio of saprophytic and pathogenic groups of microscopic fungus in soil is more than 10 , which provides sufficient suppression. Thus, the phytosanitary state of the tested soil sample improved significantly after treatment with humic extract.

When composting cattle manure and straw cutting in a ratio of $8: 1$, biohumus was obtained with humic substances content of $20.0 \mathrm{~g} / \mathrm{l}$, the sum of amino acids was 32.0 $\mathrm{g} / \mathrm{l}$.

At a microbiological research of a biohumus and humic extract from it, it is established that the largest physiological group of microorganisms in the studied biohumus is presented by aminoautotrophic microorganisms which number was $231.6 \times 10^{6} \mathrm{CFU} / \mathrm{g}$. 
The number of ammonifiers was 1.8 times lower than that of aminoautotrophies and was $130.33 \times 10^{6} \mathrm{CFU} / \mathrm{g}$. The prevalence of aminoautotrophic group over ammonifiers indicates a sufficiently high degree of mineralization of the compost. The number of cellulose-destroying actinomycetes in the biohumus under study was $0.93 \times 10^{3} \mathrm{CFU} / \mathrm{g}$, which is quite a large microbial community for this class of microorganisms, which is essential for humification and for self-purification of compost from opportunistic microorganisms.

Microbiological analysis of humic extract obtained from biohumus showed that compared to biohumus the number of studied physiological groups of microorganisms in it is tens of times less. At the same time, the number of aminoautotrophic groups was 1.8 times lower than the number of ammonium groups $-6.13 \times 10^{6}$ versus $11.23 \times 10^{6}$ CFU/g.

The experiment on estimation of influence of humic extraction on soil mycobiota showed that in 30 days after processing of soil by humic extraction the quantity of phytopathogenic micromycetes of genus Fusarium in it decreased 3.9 times, genus Penicillium - 1.2 times. The quantity of micromycetes of genus Aspergillus practically did not change, and the quantity of population of saprophyte group of micromycetes of genus Trichoderma increased 2.0 times.

After the humic extract treatment, the ratio of saprophytic and pathogenic groups of microscopic fungus in the soil is more than 10 , which ensures its sufficient suppressivity.

\section{Conclusion}

Thus, the phytosanitary state of the tested soil sample after treatment with humic extract significantly improved, which makes it possible to recommend the use of humic extract for soil treatment not only as an organic fertilizer, but also for the purpose of reducing the content of phytopathogenic microscopic fungus therein.

\section{Acknowledgement}

The authors would like to thank their colleague for their contribution and support to the research. They are also thankful to all the reviewers who gave their valuable inputs to the manuscript and helped in completing the paper. 


\section{Conflict of Interest}

The authors have no conflict of interest to declare.

\section{References}

[1] Tletseruk, I. R., et al. (2019). Degradation of the Soil Humus Content in the Takhtamukaysky District of the Republic of Adygea. International Journal on Emerging Technologies, vol. 10, issue 2, pp. 147-149.

[2] Bezverhaya, N. S., et al. (2019). The Effect of Enzymatic Modification on the Depth of Hydroliysis of Modified Protein Isolates. Amazonia Investiga, vol. 8, issue 23, pp. 43-49.

[3] Solaiman, Z. M., et al. (2018). Humus-Rich Compost Increases Lettuce Growth, Nutrient Uptake, Mycorrhizal Colonisation, and Soil Fertility. Pedosphere, vol. 29, issue 2, pp. 170-179.

[4] Li, F., et al. (2020). Spent Mushroom Substrates affect Soil Humus Composition, Microbial Biomass and Functional Diversity in Paddy Fields. Applied Soil Ecology, vol. 149, p. 103489.

[5] Zaiets, O. and Poch, R. M. (2016). Micromorphology of Organic Matter and Humus in Mediterranean Mountain Soils. Geoderma, vol. 272, pp. 83-92.

[6] Kõlli, R. (2018). Influence of Land Use Change on Fabric of Humus Cover (pro Humus form). Applied Soil Ecology, vol. 123, pp. 737-739.

[7] Ponge, J.-F. (2013). Plant-Soil Feedbacks Mediated by Humus Forms: A Review. Soil Biology and Biochemistry, vol. 57, pp. 1048-1060.

[8] Andreetta, A., et al. (2013). Microbial Activity and Organic Matter Composition in Mediterranean Humus Forms. Geoderma, vol. 209-210, pp. 198-208.

[9] Sarlaki, E., et al. (2019). Extraction and Purification of Humic Acids from Lignite Wastes using Alkaline Treatment and Membrane Ultrafiltration. Journal of Cleaner Production, vol. 235, pp. 712-723.

[10] Zou, Ch., et al. (2020). Comparison of Solid Phase Extraction Methods for the Measurement of Humic-Like Substances (HULIS) in Atmospheric Particles. Atmospheric Environment, vol. 225, p. 117370.

[11] Kanmaz, E. Ö. (2019). Humic Acid Formation during Subcritical Water Extraction of Food By-Products using Accelerated Solvent Extractor. Food and Bioproducts Processing, vol. 115, pp. 118-125. 
[12] Męczykowska, H., Stepnowski, P. and Caban, M. (2015) Impact of Humic Acids, Temperature and Stirring on Passive Extraction of Pharmaceuticals from Water by Trihexyl (Tetradecyl) Phosphonium Dicyanamide. Microchemical Journal, vol. 144, pp. 500-505.

[13] Finn, D., et al. (2016). Ecological Stoichiometry Controls the Transformation and Retention of Plant-Derived Organic Matter to Humus in Response to Nitrogen Fertilization. Soil Biology and Biochemistry, vol. 99, pp. 117-127.

[14] Qu, X., et al. (2019). Synergetic Effect on the Combustion of Lignite Blended with Humus: Thermochemical Characterization and Kinetics. Applied Thermal Engineering, vol. 152, pp. 137-146.

[15] Bernier, N. (2018). Hotspots of Biodiversity in the Underground: A Matter of Humus Form? Applied Soil Ecology, vol. 123, pp. 305-312.

[16] Rizvi, S. H., et al. (2012). Calcium-Magnesium Liming of Acidified Forested Catchments: Effects on Humus Morphology and Functioning. Applied Soil Ecology, vol. 62, pp. 81-87. 